\title{
KARYOMORPHOLOGY OF THE PHILIPPINE ROCK GOBY, Glossogobius giuris (GOBIIDAE) FROM LAKE TAAL AND SOME RIVERS OF CAVITE, LUZON ISLAND
}

\author{
JIMMY T. MASAGCA ${ }^{1}$ and JOSE A. ORDONEZ ${ }^{2}$ \\ 'Center for Multidisciplinary Research and Linkages, Graduate School of \\ Education, Arts and Sciences \\ De La Salle University-Dasmarinas, Philippines \\ ${ }^{2}$ Biological Sciences Department, College of Science \\ De La Salle University-Dasmarinas, Philippines
}

\begin{abstract}
The karyomorphology of Glossogobius giuris (Gobiidae) obtained from Lake Taal and some rivers of Cavite in Luzon Island, Philippines was described. Metaphase chromosome analysis (colchicine-sodium citrate-Carnoy's fixationGiemsa staining procedures) of the hematopoitetic cells in the anterior kidneys revealed that the diploid chromosome number was 2n=46 (46A). Fundamental Number (FN) is also 46, since all chromosomal morphology were acrocentrics without any distinguishable heteromorphic pair of chromosomes in the metaphase spreads from both dry and wet preparations. This study confirms previous reports on the chromosomal sets of G. giuris from India.
\end{abstract}

Keywords : Philippines / Lake Taal / Genetics / Karyomorphology / Glossogobius giuris

\section{INTRODUCTION}

Gobies such as Glossogobious giuris and G. celebius have been the subjects of rapidly increasing number of pollution and genetic investigations because of their readily adaptable characteristics to laboratory studies. The present karyomorpho-logical study of this popular food fish (locally named as "biya" in the Philippines) was conducted to fill in the wide gaps on fish cytogenetics in the country. Several species of gobies and other gobioid fishes (e.g. eleotrids) have been described in terms of their karyomorphological characters such as Boleophthalmus pectinirostris, Gobius abei and Periophthalmus cantonensis (Kirpichnikov 1981; Nogusa 1960).

This study sought to provide relevant information on the basic cytogenetics of Glossogobius giuris (Gobiidae), specifically, 1) to ascertain the chromosome number and fundamental number of G. giurus; 2) to construct the tentative karyo-type or ideograms of representative samples of the test fish under consideration; and 3) to describe the karyomorphological characters of the test fish.

Glossogobius giuris was the test fish selected for our chromosomal investigation since no study so far has been reported on its karyomorphology in the Philippines. Selecting G. giuris from the teleosts of Lake Taal and rivers of Cavite can be justified since cytogenetical investigations of these fishes would explain possible changes in the genetic constitution brought about by incipient speciation in our ongoing chromosome evolution studies. Moreover, empirical data gathered in this study will add to the growing body of literature on fish chromosomes that are 
needed in future studies related to cytotaxonomy, aquaculture breeding and genetoxic testing with the use of chromosomes as biomarkers.

\section{METHODOLOGY}

Fish samples of G. giuris were obtained in the waters off the Volcano Island or "Pulo" in Lake Taal and some rivers of Cavite (Dasmarinas-Indang Area and Maragondon Riverine Area). The methods used in the study basically followed the rapid flame drying techniques (with colchicinesodium citrate-Carnoy's fixation-Giemsa staining procedures) used in the previous works of Masagca (2000) and Masagca \& Sumantadinata (1994).

\section{Sample Preparation}

Fish specimens were pre-treated by intra-muscular injection with colchicine $(0.05 \%$ in $0.8 \%$ $\mathrm{NaCl}$ ) at $1 \mathrm{ml} / \mathrm{lOOg}$ body weight and allowed to swim in well-aerated glass aquaria (40 liters) for 5-6 hours (h). After treatment, the specimens were sacrificed by decapitation or hypothermia (in cracked ice) and kidneys were dissected out, carefully cleared of blood vessels and placed in a petri dish with $0.5-0.6 \%$ sodium citrate for hypotonization. Anterior kidney tissues were minced into smaller pieces for 16 to 20 minutes in the dish with the hypotonic solution. Cell suspensions are transferred to a 10-ml polypropylene tubes and centrifuged for 4-5 minutes at 2500-3500 rpm. The supernatant was removed using a Pasteur pipette without disturbing the cell pellet or cell button. About $4 \mathrm{ml}$ of the cold freshly prepared Carnoy's fixative (3 absolute methanol: 1 glacial acetic acid) was poured into the tube. After 15 minutes of periodic agitation, the cells were centrifuged again, the supernatant was removed and replaced with fresh fixative. The cell pellet was disturbed gently with a fine point needle of a disposable syringe or dissecting needle, the tube was labeled and stored in a refrigerator for 24 to $30 \mathrm{~h}$ before slide plating.

\section{Slide Plating, Staining and Chromosome Analysis}

Pre-cleaned microscope glass slides previously soaked in a 50\% ethanol and chilled in the refrigerator overnight were used. After final centrifugation, cells were re-suspended in a small volume of the fixative (about 0.5 to $0.95 \mathrm{ml}$, depending on the size of the cell button). Three to four drops of the suspension were plated on the chilled slide with a pipette and air-dried. Wet and dried slides were stained by dipping them into staining jars containing $4 \%$ Giemsa stock solution (at pH 6.8) for 30-40 minutes. Stained glass slides were rinsed with de-ionized water and dried for 
30 minutes in an improvised slide dryer. The slides are then placed in a xylene (or xylol) for 10 minutes. Slides were air dried for 15 minutes. Some slides were mounted using Entellan B. Stained slides were examined under LPO (10 x) and HPO (lOOx) to locate well-spread metaphase chromosomes. Suitable or well-spread chromosomes were screened to count the diploid chromosomes.

\section{RESULTS AND DISCUSSION}

Table 1 shows the frequency distribution of chromosome counts of G. giurus fish samples obtained from Lake Taal and selected rivers of Cavite. Using three (3) samples of G. giurus obtained from the Dasmarinas-Indang riverine areas, a total of 71 well-suited metaphase cells were screened to determine the chromosomal number (CN) as shown by the modal chromosome count. Out of this number, 52 cells or $73.24 \%$ showed a characteristic count of $2 n=46 ; 12$ cells or $16.9 \%$ with $2 n=44 ; 5$ cells with the characteristic count of 45 ; and 1 cell each for counts 43 and 47 .

Of the six (6) fish samples of G. giurus obtained from Maragondon area, there were 126 metaphase plates with 104 or $82.54 \%$ showing a CN of $2 n=46,8$ or $6.35 \%$ with $2 n=44,10$ or $7.94 \%$ with $2 n=45$; and 4 cells with 47 .

From the 12 samples of G. giurus from Lake Taal, a total of 314 well-spread metaphase cells were obtained for chromosomal analysis. Out of this number, 246 cells $(78.1 \%)$ have the characteristic count of $2 n=46$; 39 cells or $12.4 \%$ with $2 n=45$; 12 or $3.8 \%$ with $2 n=47$; 11 or $3.5 \%$ with $2 \mathrm{n}=44$ and 6 cells or $1.9 \%$ with a chromosome count of 43 .

In sum, of the 511 metaphase cells (71 metaphase cells from fish samples obtained in Dasmarinas-Indang Areas, 126 metaphase cells from Maragondon Areas and 314 metaphase cells from Lake Taal) screened, there were 402 cells or $78.7 \%$ have the diploid number of 46; 54 cells (10.5\%) have 45 ; 31 cells (6.1\%) have $44 ; 17$ cells (3.3\%) have 47 and 7 cells (1.4\%) have 43 chromosomes.

\section{Modal Chromosome Number}

Based on the data presented, the chromosomal number of the Philippine rock goby, G. giurus obtained from 3 areas showed that the diploid modal chromosome number is $2 n=46$. NF is also 46 (FN=46), since all chromosomes are mono-armed. The predominant chromosome number from the 3 locations was consistently observed at $2 n=46$ (Figure 1). This finding confirms the work of Manna (1989) from Indian samples and earlier reports of Kaur \& Srivastava (1965, as cited by Denton 1972). Although characteristic counts of 43, 44, 45 and 47 were noted in wet preparations of slides, the majority of the metaphase cells showed the chromosome count of 46 .

The chromosomal count of 45 was known in 39 cells or $12.42 \%$ of the total number of metaphase spreads. In counting chromosomes, there are instances when 
overlapping cannot be avoided. There are also possible technical reasons like a missing chromosome during slide plating.

Denton (1972) reported that within family and genus there seems to be a tendency of reduction in chromosome number to parallel speciations. Furthermore, Gold (1979) surmised that chromosome numbers and variations in chromosome number do distinguish certain taxonomic groupings, as in the case of Salmoniformes (e.g. Salmo truttd). Generalizations have already been made on chromosome numbers among the members of orders Cyprinidontiformes, Cypriniformes, Siluri-formes and Perciformes (Rishi 1989). However, it seems that gobies and eleotrids tended to show the common chromosome number of 44 to 46.

Table 1. Frequency of metaphases $(\mathrm{n}=511)$ with different chromosome number in the kidney cells of $G$. giuris.

\begin{tabular}{|c|c|c|c|c|c|c|c|}
\hline \multirow{2}{*}{ Collection Area } & \multirow{2}{*}{$\begin{array}{c}\text { Specimen } \\
\text { No. of } G \text {. giuris }\end{array}$} & \multicolumn{5}{|c|}{ Diploid Chromosome Number } & \multirow{2}{*}{$\begin{array}{c}\text { Total } \\
\text { Metaphase } \\
\text { cells }\end{array}$} \\
\hline & & 43 & 44 & 45 & 46 & 47 & \\
\hline \multirow{4}{*}{$\begin{array}{l}\text { Dasmarinas-Indang } \\
\text { Areas }\end{array}$} & 1 & 1 & 6 & 4 & 15 & 1 & 27 \\
\hline & 2 & - & 1 & 1 & 9 & - & 11 \\
\hline & 3 & - & 5 & - & 28 & - & 33 \\
\hline & Total & 1 & 12 & 5 & 52 & 1 & 71 \\
\hline \multirow{7}{*}{$\begin{array}{l}\text { Maragondon } \\
\text { Areas }\end{array}$} & 1 & - & 2 & 1 & 7 & 2 & 12 \\
\hline & 2 & - & 1 & 3 & 32 & - & 36 \\
\hline & 3 & - & 1 & - & 19 & 1 & 21 \\
\hline & 4 & - & - & 4 & 12 & - & 16 \\
\hline & 5 & - & 3 & 2 & 6 & 1 & 12 \\
\hline & 6 & - & 1 & - & 28 & - & 29 \\
\hline & Total & 0 & 8 & 10 & 104 & 4 & 126 \\
\hline \multirow[t]{12}{*}{ Pulo, Lake Taal } & 1 & 3 & 2 & 1 & 5 & 1 & 12 \\
\hline & 2 & - & 1 & - & 23 & - & 24 \\
\hline & 3 & - & - & 3 & 51 & - & 54 \\
\hline & 4 & - & - & 1 & 8 & 1 & 10 \\
\hline & 5 & 1 & 5 & - & 17 & - & 23 \\
\hline & 6 & 2 & - & 1 & 44 & - & 47 \\
\hline & 7 & - & - & - & 9 & 3 & 12 \\
\hline & 8 & - & - & - & 7 & 4 & 11 \\
\hline & 9 & - & 2 & 3 & 26 & 1 & 32 \\
\hline & 10 & - & - & 7 & 10 & - & $\begin{array}{l}17 \\
43\end{array}$ \\
\hline & $\begin{array}{l}11 \\
12\end{array}$ & - & $i$ & $\begin{array}{c}9 \\
14\end{array}$ & $\begin{array}{l}34 \\
12\end{array}$ & $\overline{2}$ & $\begin{array}{l}43 \\
29\end{array}$ \\
\hline & Total & 6 & 11 & 39 & 246 & 12 & 314 \\
\hline
\end{tabular}


Total No. of Metaphase Cells Screened $=\mathbf{5 1 1}$

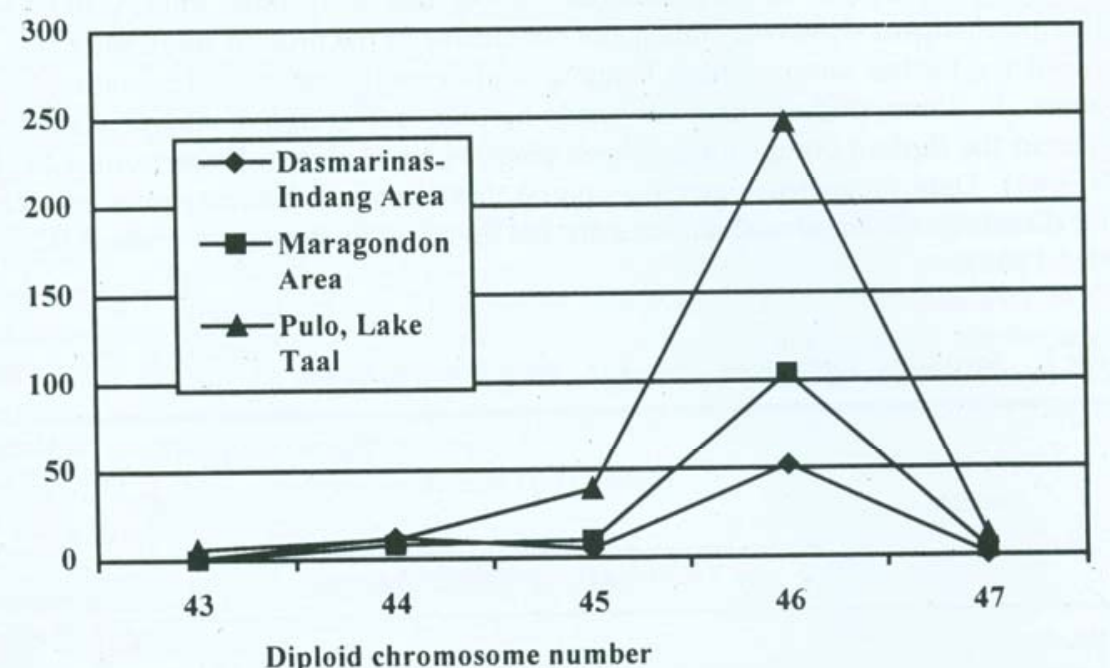

Diploid chromosome number

Figure 1. Chormosome counts of G. giuris from different locations in Cavite and Lake Taal.

The karyotype of G. giuris consists of 46 acrocentric chromosomes. Since an acrocentric chromosome is counted as only one arm, the total number of arms will also be 46 . The centromere of acrocentric type of chromosome is terminal on which produces a chromosome with one long arm. The karyotypes of the gobies Boleoph-thalmus pectinirostris, Gobius abei and Periophthalmus cantonensis were also found to have $2 n=46$ (all acrocentrics) as reported in the studies of Kirpichnikov (1981) and Nogusa (1960).

\section{Karyomorphological Characters of G. giuris}

As shown in Tables 1 and 2, the diploid chromosome number, 2n=46 obtained for G. giuris was consistent in 3 locations (Dasmarinas-Indang Areas, Maragondon Areas and Pulo (I and II) in Lake Taal.

In the Gobiidae family, most of the genera have chromosome number of $2 n=44$ to $2 n=48$, such as in Bathygobius fuscus $(2 \mathrm{n}=48)$ and Chaetogobius annularis $(2 \mathrm{n}=44)$. The chromosomes of gobies and eleotrids show variability from $2 n=43$ to 62 (Masagca 2000), with most of the chromosome numbers are $2 \mathrm{n}=44,46$ and 48 . In another study, the karyotype of G. microdon has a diploid number of $2 \mathrm{n}=56$ and NF of 66 with a chromosome formula of $4 \mathrm{M}+6 \mathrm{SM}+46 \mathrm{ST}$, A. 
Variability in chromosomal counts would lead to certain generalization of the possibility of changes in chromosomal number due to fusions, translocations and other mechanisms. However, this is not conclusive in the present study since there is a need for further chromosomal banding studies and constancy of variation in the counts. In some studies, like the paedomorphic goby, Aphia minuta (Gobiidae) wherein the diploid complement ranged from 44 to 41 due to Robertsonian fusions ( $\mathrm{NF}=44$ ). Data on spermatogenesis suggest that structural heterozygotes are fertile and that these chromosomal changes are not involved in speciation process (Caputo et al. 1999).

Table 2. Summary of chromosome counts for G. giuris from 3 locations.

\begin{tabular}{lllllll}
\hline \multicolumn{1}{c}{ Location } & \multicolumn{1}{c}{ Diploid (2n) Chromosome Number } & & $\begin{array}{c}\text { Total } \\
\text { No. of } \\
\text { Metaphase } \\
\text { Cells }\end{array}$ \\
& & & & & \\
& 43 & 44 & 45 & 46 & 47 & 71 \\
\hline Dasmarinnas Indang Area & 1 & 12 & 5 & 52 & 1 & 126 \\
Maragondon Areas & 0 & 8 & 10 & 104 & 4 & 314 \\
Pulo I \& 11, Lake Taal & 6 & 11 & 39 & 246 & 12 & 511 \\
Total & 7 & 31 & 54 & 402 & 17 & $(100)$ \\
Percent (\%) & $(1.4)$ & $(6.1)$ & $(10.5)$ & $(78.7)$ & $(3.3)$ & \\
\hline
\end{tabular}

In this study, characteristic counts of $41,42,43,44$ and counts higher than 46 in the test animals (G. giurus) were observed. Variations in chromosome number maybe attributed to several factors: (1) handling techniques; (2) chemically induced; and (3) inherent genetic characteristic of the test fishes. Handling techniques would explain the variability in chromosome counts.

The karyotypes of two other teleosts, G. giurus previously described in Japan, India and elsewhere could permit the researchers to have further comparison using the conventionally stained chromosomes and in the future the banded chromosomes from fully elongated chromosomes.

Diploid chromosome number of the Philippine common goby, G. giuris is $2 n=46$ and NF of 46. All of the chromosomes are acrocentric (mono-armed). The chromosome number of 46 is common to the order Perciformes. Diploid chromosome number of Oxyeleotris aporos is $2 \mathrm{n}=46$, which is also similar to the chromosomes of Selene setapinnis (family Carangidae) as described by Netto \& Pauls (2000).

In fishes, 48 rod-like chromosomes have been considered to be the modal number as shown in the works of Nogusa (1960), Roberts (1967) and Ohno \& Atkin 
(1968). Recently Manna (1989) advocated that 48 chromosomes mixed morphology and only rods were the modal ones from which the evolution of different karyotypes can be envisaged.

\section{CONCLUSION}

This study concluded that the Philippine rock goby, G. giuris has a diploid chromosome formula of $2 n=46$ (A) and having the fundamental number of 46. Karyomorphological characters of the goby under study reveal that majority of the chromosomal spreads consist of all acrocentric chromosomes, which are common among the gobiids and eleotrids. No heteromorphic pair of chromosomes was observed in the ideograms prepared. Characteristic chromosome counts of G. giuris range from 41 to 48.

\section{ACKNOWLEDGMENT}

The authors express their thanks to the DLSU-D administrators (Dr. H.D. Torres, Dr. MF. Ramos, Dr. V.L. de Leon, Dr. N.M. Medina, Ms. C. Cervillon and Dr. J. Samonte for the UFRO grant.

\section{REFERENCES}

Arai, R. and Y. Sawada. 1974. Chromosomes of Japanese gobioid fishes (I). Bulletin of Natural Science Tokyo 17:97-102.

Arai, R. and A. Fujiki. 1979. Chromosomes of Japanese gobioid fishes (IV). Bulletin of the Natural Science Museum. Series A 5 (2): 153-159.

Caputo, V., M. L. Caniglia and N. Machella. 1999. The chromosomal complement of Aphia minuta, a paedomorphic goby. The Fisheries Society of the British Isles, p. 455-458.

Denton, T.E. 1972. Fish chromosome methodology. Charles C. Thomas Publisher, Springfield, Illinois. 166 p.

Kaur, D. and M.D.L. Shrivastava. 1965. The structure and behavior of chromosomes in freshwater teleosts. Cited by Denton, T.E.1973. Fish chromosome methodology. Berlin: Charles C. Thomas Publishing. Springer Verlag.

Kirpichnikov, V.S. 1981. Genetic bases for fish selection. Springer Verlag: Berlin.

Kligerman, A.D. and S.E. Bloom. 1977. Rapid chromosome preparations from solid tissues of fishes. Journal of the Fisheries Research Board Canada, 23:266-269.

Levan, A., K. Fredga and A. Sanberg. 1964. Nomenclature for centromeric position on chromosmes. Hereditas, 52:201.

Manna, G.K.I 989.Fish cytogenetics related to taxonomy, evolution and monitoring genotoxic agent. Pages 2146, In: Das and Jhingran, eds. Fish Genetics in India. Today and Tomorrow Printer \& Publishers: New Delhi, India. 
Masagca, J.T. 2000.Karyology of the South-East Asian marble sleeper, Oxyeleotris marmorata Bleeker 1852. Asian International Journal of Life Sciences Journal, 9(2):181-188.

Masagca, J.T. and K. Sumantadinata. 1994. Chromosomal characters of the Indonesian sand goby, oxyeleotris marmorata Blkr. 1874 (Eleotridae), BIOTROPIA-Southeast Asian Journal of Tropical Biology (7): 41-46.

Masagca, J.T. 1993. Karyotypic differentiation among natural populations of sand goby. O. marmorata Blkr. (Eleotridae) in the Indo-Malayan region. Proceedings of the Symposium on Fish Genetics and Its Application to Fishery Management held on Dec. 8-11, 1992, SEAMEO-BIOTROP Bogor, Indonesia.

Medina, F.I.S. III. 1984. A simple method for studying the mitotic metaphase of Tilapia nilotica. Proc. Symp. Research Trends Phils. NRCP Bull. No. 98.

Netto, M.R.C.B. and E. Pauls. 2000. Family Carangidae: Cytogenetical and evolutionary aspects (International Workshop on Marine Genetics, 1998 (Brazil).

Nogusa, S. 1960. A comparative study of the chromosomes in fishes with particular considerations on the taxonomy and evolution. Memoir of Hyogo University of Agriculture 3(1):1.Cited by Denton, T.E.I973.Fish chromosome methodology. Charles C. Thomas Publishing. Springer Verlag, Berlin. 166p.

Ohno and Atkin. 1968. Evolution from fish to mammals by gene duplication. Hereditas, 59:169-187.

Pagulayan, R.C., N.C. Lopez and F.S. Magbanua. 1997. Littoral fishes of Lake Taal. Sylvatrop Tech. J. of Philipp. Ecosystems and Mat Res. 7(1\&2):84-93.

Reddy, P.V.G.K. and G. John. 1987. A method to increase mitotic metaphase spreads in permanent chromosome preparations for karyotype studies of fishes. Pages 199-205. In: Proceedings of the World Symposium on Selection, Hybridization and Genetic Engineering in Aquaculture held in Bordeaux. 27-30 May 1986. Vol. II.

Rishi, K..K. 1989. Current status of fish cytogenetics. Pages 1-20, In: Das and Jhingran (eds.), Fish Genetics in India. Today and Tommorow's Printers and Publishers, New Delhi, India.

Rivlin, K., J.W. Rachlin and G. Dale. 1985. A simple method for the preparation of fish chromosomes applicable to field work, teaching and banding. Journal of Fish Biology, 26:267-272.

Roberts, E.L. 1967. Chromosome cytology of the Osteichthyes. Progressive Fish Culturist, 29:75-83.

Sumner A.T., H.J. Evans and R.A. Buckland. 1971. A new technique for distinguishing between human chromosomes. Nature New Biol. 232:31-32. 